\title{
DOUBLE-BLIND PROSPECTIVE RANDOMIZED STUDY COMPARING POLYETHYLENE GLYCOL TO LACTULOSE FOR BOWEL PREPARATION IN COLONOSCOPY
}

\author{
Estudo prospectivo randomizado duplo-cego comparando polietilenoglicol com lactulose para preparo de cólon em colonoscopia \\ Aline Moraes MENACHO, Adriano REIMANN, Lie Mara HIRATA, \\ Caroline GANZERELLA, Flavio Heuta IVANO, Ricardo SUGISAWA
}

From the Serviço de Endoscopia do Hospital de Caridade Irmandade Santa Casa de Misericórdia de Curitiba, Curitiba, PR, Brazil

HEADINGS - Colonoscopy. Bowel preparation. Polietilenoglicol. Lactulose.
ABSTRACT - Background: Colonoscopy is the most frequent exam used to evaluate colonic mucosa, allowing the diagnosis and treatment of many diseases. The appropriate bowel preparation is indispensable for the realization of colonoscopy. Therefore, it is necessary the use of laxative medications, preferentially by oral administration. Aim: To compare two medications used in bowel preparation in adult patients going to ambulatory colonoscopy and to analyze the patients' profile. Methods: A double-blind prospective study with 200 patients, randomized in two groups: one that received polyethilene glycol and another that received lactulose. The patients answered to questionnaires to data compilation, as tolerance, symptoms and complications related to preparation. Besides, it was also evaluated the prepare efficacy related to the presence of fecal residue. Results: Intestinal habit alterations and abdominal pain were the main reasons to realize the exams and hypertension was the most prevalent comorbidity. Ten percent of the ones who received lactulose didn't get to finish the preparation and $50 \%$ considered the taste "bad, but tolerable". The most common subjective symptom after the medication was nausea, especially after lactulose. During the exam, most of the patients who used lactulose had a "light discomfort" and the ones who used polyethilene glycol considered the discomfort as "tolerable". The quality of the preparation was good in $75 \%$, undependable of the medication that was used. Conclusion: Polyethilene glycol was more tolerable when compared to lactulose, without difference on the quality of the preparation.

\section{Correspondence:}

Aline Moraes Menacho

E-mail: alinemenacho@yahoo.com.br

Financial source: none

Conflicts of interest: none

Received for publication: 19/08/2013

Accepted for publication: 10/12/2013

DESCRTORES - Colonoscopia. Preparo de colon. Polietilenoglicol. Lactulose
RESUMO - Racional - A colonoscopia é o exame mais utilizado atualmente para avaliação da mucosa colônica, permitindo diagnóstico e tratamento de diversas doenças. O preparo de cólon adequado é imprescindível para a realização do exame. Para tanto, é necessária a utilização de laxantes, cuja via preferencial de preparo é a oral. Objetivo - Comparar duas soluções para preparo de cólon nos pacientes adultos a serem submetidos à colonoscopia em regime ambulatorial e o perfil destes pacientes. Métodos - Estudo prospectivo duplo-cego com 200 pacientes distribuídos aleatoriamente em dois grupos: um que recebeu dose padrão de polietilenoglicol e o outro que recebeu dose padrão de lactulose. Os pacientes responderam a questionários para compilação de dados, como tolerância, sintomas e complicações relacionadas ao preparo. Além disso, foi avaliada também a eficácia do preparo com relação à presença de resíduos fecais. Resultados - Alteração do hábito intestinal e dor abdominal foram os principais motivos para o exame, sendo que hipertensão a comorbidade mais prevalente. Dez por cento dos que receberam lactulona não conseguiram completar o preparo e $50 \%$ consideraram o gosto do preparo "ruim, mas tolerável". O sintoma subjetivo mais comum após o preparo foi náusea, principalmente após a lactulona. Durante o exame, a maioria dos usuários da lactulona teve desconforto "leve", sendo que os que usaram polietilenoglicol consideraram o desconforto como "tolerável". A qualidade do preparo foi boa em $75 \%$, independentemente do preparo utilizado. Conclusão - O polietilenoglicol apresentou melhor tolerância quando comparado à lactulona, não havendo diferença na qualidade do preparo. 
INTRODUCTION

$\mathrm{N}$ owdays colonoscopy is the most useful exam for evaluation of colonic mucosa. The indications include investigation for intestinal bleeding, changes in the bowel habits and colorectal cancer screening.

In the colonoscopy the success depends on the quality of the bowel preparation that aims to empty the colon of all fecal material, permitting adequate visualization of the mucosal surface. The preparation of the colon is considered an appropriate factor directly associated to the correct diagnostic, lower chance of complications, low cost and patients complaints.

The preference is oral preparation - except for the suspected bowel obstruction and temporary ileostomy - for its simplicity and better efficacy compared to enemas requiring introduction of tubes or rectal probes. It is different, according to the type and dose of laxative, the volume of fluid to be ingested and the diet. More recent studies have observed other parameters, like taste, electrolyte supplementation, administration times and doses division. ${ }^{1}$

The ideal preparation should cleanse the colon quickly without causing histological changes in the mucosa, be at low cost and free or with minimal side effects, such as abdominal discomfort and electrolyte changes. Depending on the drug used, the anterograde preparation induces peristalsis and intestinal spasms responsible for symptoms, such as cramping and bloating, and induces watery diarrhea with electrolyte losses (thirst, dizziness, asthenia, postural hypotension) and anal discomfort. The preparation intolerance (nausea and vomiting) is usually associated with the volume of fluid consumed and the taste.

The ideal laxative should be on reduced volume, palatable, with minimal side effects and low cost. No laxative includes all criteria, and so there are many colon preparations to be administered according to the clinical situation. Recent consensus have demonstrated the efficacy and safety of different formulations, including polyethylene glycol, but this one with the administration disadvantage to drink at four liters ${ }^{2}$. Lactulose is a laxative described for medical treatment of hepatic encephalopathy in patients with cirrhosis, as well as constipation. Its use in bowel preparation for colonoscopy is considered effective with similar results when compared to manitol ${ }^{3}$.

In a recent review, a list with several medications and different forms of bowel preparation can be appreciated ${ }^{1}$. Drugs such as sodium phosphate, polyethylene glycol and sodium picosulfate magnesium citrate underwent several randomized studies in order to verify the effectiveness and tolerance. No study compared polyethylene glycol and lactulose.

Polyethylene glycol (Muvinlax ${ }^{\circledR}$ or Nulytely ${ }^{\circledR}$ ) is a non-absorbable solution electrolytic and does not induce mucus secretion of electrolytes or reduce significant exchange of fluid in colonic lumen. It has been shown to be nontoxic and can be ingested in large quantities without dangerous effects ${ }^{3,4}$. It's use is relatively safe in patients with renal failure, with cirrhosis or congestive heart failure ${ }^{3}$. The main disadvantage is the need of drinking a lot of liquids (four liters). Although it is effective, it is associated with intolerance in up to $15 \%$ of patients. Recent studies with low dose (two liters) when associated with bisacodyl and magnesium citrate have shown better tolerance ${ }^{3}$. The usual dosage is $240 \mathrm{ml}$ of the product diluted in water (as manufacturers' orientations) every ten minutes until clear liquid goes out through the anus at maximum intake of four liters. It is recommended not to eat solid food before ingestion of the solution. The dose by nasogastric probe is 20 to $30 \mathrm{ml}$ per minute (1.2-1.8 $\mathrm{l} / \mathrm{h})^{3}$.

Lactulose (Duphalac ${ }^{\circledR}$ ) is a disaccharide, semi-synthetic derivative of lactose. It is absorbed and undergoes bacterial action, which causes fermentation, acidifying the environment and causing acceleration of intestinal transit by stimulating motility ${ }^{3}$. Another consequence of acidification is increased osmotic pressure within the lumen of the colon, proportional to the dose ${ }^{4}$. Regarding dosage, $120 \mathrm{ml}$ is diluted with juice or clear water to make $1000 \mathrm{ml}$ swallowing all volume within $1 \mathrm{~h}^{5}$.

Use of lactulose for colon preparation in doses of $10 \%$ and $50 \%$ showed similar efficacy compared to $10 \%$ mannitol $^{5}$. In a study of 2000 consecutive patients, the lactulose with above way of administration showed efficacy good in $84.8 \%$, fair in $9.2 \%$ and poor in $5.9 \%$ of cases. The preparation intolerance (inability to drink all the solution) was observed in $3.3 \%$ of patients. So, studies to evaluate the efficacy, tolerance and cost comparing polyethyleneglycol and lactulose in the colon preparation may contribute to the routine of patients undergoing colonoscopies.

The objective of this study was to performed a prospective double-blind study, comparing the above two types of solutions for bowel preparation analyzing tolerance, symptoms, complications and efficacy.

\section{METHODS}

This study was conducted at Hospital Santa Casa de Curitiba, Brazil from January 2011 to January 2012. After the review and approval of 
the institution's Research Ethics Committee, 200 patients were selected from the Brazilian National Health System referred to elective colonoscopy performed in Endoscopy Service of Santa Casa de Misericórdia de Curitiba. They were informed about the bowel preparation based on lactulose or polyethylene glycol. To each patient randomly selected was given a box containing one of the two preparations, double-blindly done. The product label was covered and the patients received specific instructions for preparation without the presence of the researchers. Each box was labeled with a number and recorded on a record that was held closed by the researchers, who only opened the envelope in case of any problem related to the preparation and statistical evaluation at the end of the study. Patients considered eligible for the study signed an informed consent. They had free will to choose or not to enter the trial. Patients who did not wanted to be enrolled received the usual preparation.

As inclusion criteria, the patient was considered eligible when had clinical conditions to oral bowel preparation. Exclusion criteria were patients with ileostomy, with prior colonic resection, with excluded colonic segment, suspected of bowel obstruction, severely ill, unable to oral intake, aged below 13 years old, weighing less than $50 \mathrm{~kg}$, pregnant and those who refuse to participate in the study.

Two evaluations were performed, one at least three days before the colonoscopy and the other on the day of the study. The first evaluation, consisted of a questionnaire to collect data, in which questions about the reason for the examination, digestive symptoms, morbid history and current health status were formulated and maintained closed. The second evaluation, consisted of questions related to bowel preparation, also maintained closed. The colonoscopy was performed in the usual way. The findings during colonoscopy and the quality of the preparation were recorded with standardized scale based on visual estimation of fecal residues observed during the exam (Figure 1).

\begin{tabular}{|c|c|}
\hline Scale & Quality of bowel preparation \\
\hline Excellent & $\begin{array}{l}\text { Small amount of clear liquid or more than } 95 \% \\
\text { of mucosa visualization }\end{array}$ \\
\hline Good & $\begin{array}{l}\text { Large volume of clear liquid covering } 5 \text { to } 25 \% \\
\text { of the mucosa, but with visualization of more } \\
\text { than } 90 \% \text { of the mucosa }\end{array}$ \\
\hline Regular & $\begin{array}{l}\text { Some aspirate feces or soft stools permitting } \\
\text { visualization of at least } 90 \% \text { of the mucosa }\end{array}$ \\
\hline Bad & $\begin{array}{l}\text { Feces not subject to washing or aspiration, permitting } \\
\text { visualization of less than } 90 \% \text { of the mucosa }\end{array}$ \\
\hline Inadequate & $\begin{array}{l}\text { Bowel preparation incompatible with the exam } \\
\text { needing to be repeated after appropriate } \\
\text { preparation }\end{array}$ \\
\hline
\end{tabular}

FIGURE 1 - Scale of quality for bowel preparation
RESULTS

The main colonoscopy indications were alterations in bowel habits and abdominal pain. Sixty percent of patients had comorbidities, being hypertension the most prevalent; $10 \%$ of those receiving lactulona and $4 \%$ who received polyethylene glycol failed to complete the preparation; $50 \%$ considered the taste of the preparation "bad, but tolerable" - mainly those receiving lactulona. The most common subjective symptoms after preparation was nausea, especially after lactulona. During the exam, most users of lactulona had "mild" discomfort, and those using polyethylene glycol felt discomfort as "tolerable". The quality of the preparation according to the scale of Aronchick was "good" in 75\%, regardless of the preparation used. Thus, polyethylene glycol showed better tolerance when compared to lactulona, with no difference in quality of the preparation (Figure 2).

\section{SINTOMAS SUBJETIVOS DOS PREPAROS}

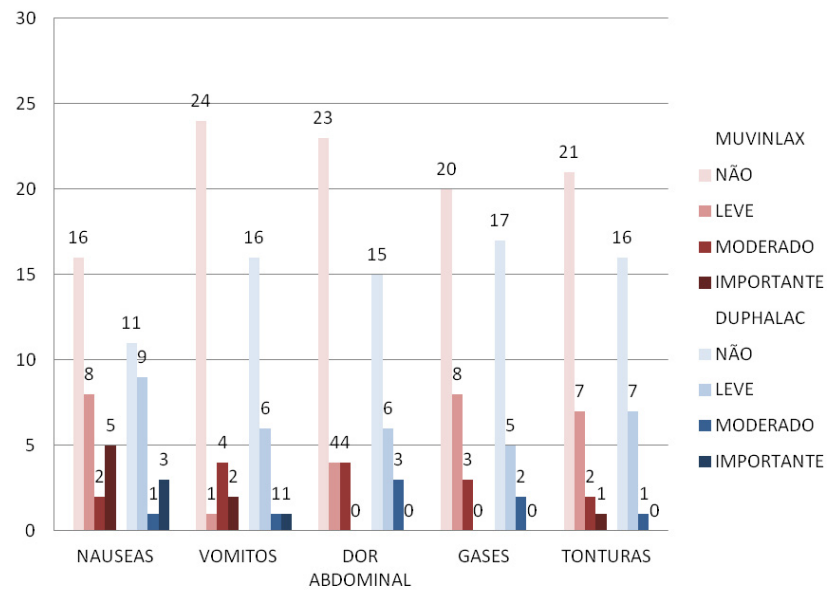

FIGURE 2 - Subjective symptoms of preparations

\section{DISCUSSION}

The bowel preparation for colonoscopy is vital for good visualization of the mucosa of the evaluated segments. This procedure must be performed in appropriate way, with low discomfort for patients and high accuracy. The anterograde (oral) administration is more frequently used, and may induce strong peristalsis, cramping, bloating, diarrhea, among others symptoms. The preparation intolerance is common and is usually associated with the volume of fluid consumed and the taste of the solution.

No laxative has all the characteristics of an ideal medication (low volume, palatable, with minimal side effects and low cost). 
Among the more frequently used preparations are polyethylene glycol, lactulose, mannitol, with their specific advantages and disadvantages. It becomes necessary, therefore, a detailed analysis of each solution trying to use the best in the various clinical situations that the doctors are faced.

\section{CONCLUSIONS}

Lactulona was considered less tolerable by the patients in bowel preparation compared to polyethylene glycol; both have the same quality in the preparation for the exam.

\section{REFERENCES}

1. Burke CA, Church JM. Enhancing the quality of colonoscopy: the importance of bowel purgatives. Gastrointest Endosc 2007; 66(3):565-73.

2. Schumann C. Medical, nutritional and technological properties of lactulose. An update. Eur J Nutr 2002; 41 (1):17-25.
3. Manzione CR, Nadal SR. Preparo domiciliar de cólon com bisacodil e solução de lactulose a 10 por cento para colonsocopia ambulatorial. Rev Bras Coloproctol. 2000; 20(2):91-4.

4. Ferguson A, Culbert $P$, Gillett $H$, Barras N. New polyethylene glycol electrolyte solution for the treatment of constipation and faecal impaction. Ital J Gastroenterol Hepatol. 1999 31(3):249-52.

5. Nardulli G. Use of polyethylen glycol in the treatment of puerperal constipation. G E N. 1995. 49:224-26.

6. Stewart RB, Moore MT, Marks RG, Hale WE. Correlates of constipation in an ambulatory elderly population. Am J Gastroenterol. 1992; 87(7): 859-64.

7. Marschall HU, Bartels F. Life-threatening complications of nasogastric administration of polyethylene glycol-electrolyte solutions (Golytely) for bowel cleansing. Gastrointest Endosc. 1998; 47(5): 408-10.

8. Adams WJ, Meagher AP, Lubowski DZ, King DW. Bisacodyl reduces the volume of polyethylene glycol solution required for bowel preparation. Dis Colon Rectum. 1994; 37 (3): 229-33.

9. Panton ON, Atkinson KG, Crichton EP, Schulzer M, Beaufoy $A$, Germann E. Mechanical preparation of the large bowel for elective surgery. Comparison of whole gut lavage with conventional enema and purgative technique. Am J Surg. 1985; 149(5): 615-9.

10. Mortensen PB, Rasmussen HS, Holtug K. Lactulose detoxifies in vitro short-chain fatty acid production in colonic contents induced by blood: implications for hepatic coma. Gastroenterology. 1988; 94(3):750-54 